\title{
Snake melon asteroid mosaic virus, a Tentative New Member of the Genus Sobemovirus Infecting Cucurbits
}

Hervé Lecoq, INRA, UR407, Station de Pathologie Végétale, B.P. 94, 84143 Montfavet Cedex, France; Gasim Dafalla, Plant Pathology Center, University of the Gezira, Wad Medani, Sudan; and Brigitte Delécolle, Catherine Wipf-Scheibel, and Cécile Desbiez, INRA, France

\begin{abstract}
Lecoq, H., Dafalla, G., Delécolle, B., Wipf-Scheibel, C., and Desbiez, C. 2011. Snake melon asteroid mosaic virus, a tentative new member of the genus Sobemovirus infecting cucurbits. Plant Dis. 95:153-157.

A virus isolate ( $\mathrm{Su}-95-67)$ was obtained from a snake melon (Cucumis melo var. flexuosus) plant presenting severe chlorotic spots, mosaic, stunting, and leaf deformations collected in Eastern Sudan in 1995. Su95-67 was easily mechanically transmissible and had a host range limited to a few cucurbit species. Isometric virus particles approximately $30 \mathrm{~nm}$ in diameter were observed in leaf dip preparations. A cytopathological study did not reveal alterations specific for a virus genus or family. A polyclonal antiserum was obtained and used in double-antibody sandwich enzyme-linked immunosorbent assay (DASELISA). Su-95-67 was transmitted by seed at a low rate, by the red melon beetle (Aulacophora foveicollis), but not by the melon aphid

(Aphis gossypii). Because Su-95-67 shared several properties with sobemoviruses, generic Sobemovirus reverse-transcription polymerase chain reaction primers were developed. They allowed amplification of a 384-bp fragment from extracts of plants infected by two sobemoviruses or by Su-95-67 but not from healthy plants extracts. Sequence comparison confirmed that Su-95-67 belongs to a new tentative Sobemovirus species for which we propose the name Snake melon asteroid mosaic virus (SMAMV). DAS-ELISA tests conducted on extracts of virus-infected cucurbit plants collected from 1992 to 2003 revealed the presence of SMAMV in $10.2 \%$ of 600 samples originating from different regions of Sudan.
\end{abstract}

Cucurbits are important vegetable crops in Sudan. They are grown in many regions and in a variety of agroecosystems (including rain-fed, flood-irrigated, and permanently irrigated conditions) with a diversity of technical inputs. The major cultivated species are sweet melon (Cucumis melo var. inodorus), snake melon (also called snake cucumber; $C$. melo var. flexuosus), tibish (a cultivated form of C. melo var. agrestis), squash (Cucurbita pepo), and watermelon (Citrullus lanatus). In addition, a number of wild cucurbit species are present in the environment of cultivated areas.

Cucurbit crops in Sudan are severely affected by several viruses causing yellowing or mosaic diseases and important yield losses (7). A 10-year survey has shown that the most common cucurbit viruses in this country are Cucurbit aphid borne yellows virus (CABYV, Polerovirus), Zucchini yellow mosaic virus (ZYMV, Potyvirus), Watermelon chlorotic stunt virus (WmCSV, Begomovirus), Moroccan watermelon mosaic virus (MWMV, Potyvirus), and Squash mosaic virus (SqMV, Comovirus) (6).

In addition, severe mosaic, stunting, and leaf deformation symptoms were occasionally observed on melon, snake melon, or watermelon plants in which none of the known mosaic-inducing virus was detected by double-antibody sandwich enzyme-linked immunosorbent assay (DAS-ELISA). Isometric virus particles approximately $30 \mathrm{~nm}$ in diameter were consistently observed in leaf extracts of such plants. One isolate ( $\mathrm{Su}$ 95-67) was further characterized and, in this article, we report that this cucurbit virus belongs to a tentative new species of genus Sobemovirus that we propose to name Snake melon asteroid mosaic virus (SMAMV). This name is derived from the host from which it was first isolated

Corresponding author: H. Lecoq, E-mail: Herve.Lecoq@avignon.inra.fr

GenBank accession number for nucleotide sequence of SMAMV is HM450304.

Accepted for publication 31 August 2010.

doi:10.1094/PDIS-06-10-0447

(C) 2011 The American Phytopathological Society (snake melon) and from the typical symptoms it induces in this host (star-shaped chlorotic spots and mosaic).

\section{Materials and Methods}

Virus isolate and host range study. The virus isolate characterized in this study (Su-95-67) was obtained from a naturally infected snake melon (Cucumis melo var. flexuosus) plant collected in December 1995 near Abou Rakham, Sudan. The original infected plant showed severe symptoms of chlorotic spots, mosaic, stunting, and leaf deformation on the young leaves and yellowing symptoms on the older leaves. This plant was found by DASELISA to be devoid of other mosaic-inducing viruses, including ZYMV, SqMV, WmCSV, MWMV, Papaya ringspot virus (PRSV, Potyvirus), and Cucumber mosaic virus (CMV, Cucumovirus), but it was infected by CABYV, the probable cause of the yellowing symptoms observed on the older leaves. Isolate Su-95-67 could be easily separated from CABYV through mechanical inoculation, because CABYV is not mechanically transmissible.

Leaves from infected plants were triturated with $0.03 \mathrm{M}$ $\mathrm{Na}_{2} \mathrm{HPO}_{4}$ containing $0.2 \% \mathrm{Na}$-diethyldithiocarbamate (DIECA) $(1: 5 ; \mathrm{wt} / \mathrm{vol})$ with a mortar and pestle. Extracted juice was mixed with 400-mesh Carborundum $(75 \mathrm{mg} / \mathrm{ml})$ and activated charcoal $(75 \mathrm{mg} / \mathrm{ml})$ before being rub inoculated on test plants. The susceptibility of 23 plant species belonging to eight families was evaluated following mechanical inoculation of two plants for each species. The presence of the virus was checked by DAS-ELISA using homologous antibodies, 2 weeks after inoculation in the inoculated leaves and the plant apex and 7 to 10 days later in the plant apex only. The host range study was repeated three times.

Seed and vector transmission experiments. Melon (cv. Védrantais) and snake melon (a local cultivar from Sudan) plants were mechanically inoculated at the two-leaf stage, transplanted 2 weeks later in larger pots, and kept in an insect-proof glasshouse with regular fertilization and pesticide applications. Plants were selfed by hand pollination and 26 fruit from infected melons (Védrantais and snake melon) were collected at maturity. Seed were either rinsed in tap water or disinfected using maceration for $24 \mathrm{~h}$ in a solution containing a pectinase enzyme (Rapidase Excolor; Gist Brocades, France) at $0.3 \mathrm{~g} / \mathrm{liter}$ and $\mathrm{HCl}$ (a 33\% solu- 
tion at $6.7 \mathrm{ml} / \mathrm{liter}$ ), then rinsed three times in tap water and dried at room temperature.

Seedlings were raised from the different seed lots in insect-proof glasshouses. The presence of the virus in seedlings was first determined by visual assessment and confirmed by DAS-ELISA.

Aphid transmission experiments were conducted at Montfavet (France) with Aphis gossypii, the melon aphid, which is frequently observed on snake melon in Sudan. Nonpersistent, semipersistent, and persistent transmission conditions were tested, with acquisition access periods (AAPs) of $5 \mathrm{~min}, 12 \mathrm{~h}$, and $48 \mathrm{~h}$, respectively, and inoculation access periods (IAPs) of 2, 24, and $48 \mathrm{~h}$, respectively. After the acquisition periods, aphids were deposited by groups of five on each of 10 melon test plants.

Beetle transmission experiments were conducted at Wad Medani (Sudan) with Aulacophora foveicollis, the red melon beetle, a severe pest of cucurbit crops in Sudan. Beetles were reared on healthy snake melon plants. Adults were placed on Su-95-67infected snake melon plants for a 3-h AAP. Beetles were then transferred by groups of three to healthy snake melon plants for a 2-h IAP. Control plants received groups of three beetles from the healthy mass rearing.

After the inoculation periods, plants were sprayed with insecticides before being transferred to insect-proof greenhouses in each location. Symptoms were noted 2 weeks later and transmission was confirmed by serology. The aphid and beetle transmission tests were repeated twice.

Virus purification and antiserum production. Su-95-67 isolate was purified from infected melon plants 3 weeks after inoculation. Infected leaves $(50 \mathrm{~g})$ were homogenized in $150 \mathrm{ml}$ of $0.5 \mathrm{M}$ potassium phosphate buffer, $\mathrm{pH} 7.5$, containing $25 \mathrm{mM}$ DIECA and $0.2 \% \mathrm{NaSO}_{3}$. The extract was emulsified in $75 \mathrm{ml}$ of cold chloroform and clarified by low-speed centrifugation at $10,000 \times g$ for $10 \mathrm{~min}$. The aqueous phase was incubated with $1 \%$ Triton X100, $6 \%$ polyethylene glycol 6000 , and $0.1 \mathrm{M} \mathrm{NaCl}$ and kept under gentle stirring for $1 \mathrm{~h}$ at $4{ }^{\circ} \mathrm{C}$. The precipitate was collected by lowspeed centrifugation and resuspended in 1/10th of the original volume in $0.02 \mathrm{M}$ potassium phosphate buffer, $\mathrm{pH}$ 7.5. After one cycle of high-speed centrifugation $(2 \mathrm{~h} 30 \mathrm{~min}$ at 35,000 rpm in a Beckman 50.2 rotor), pellets were resuspended in a small volume of $0.02 \mathrm{M}$ phosphate buffer. The preparation was then submitted to an equilibrium density-gradient centrifugation in $\mathrm{CsCl}(16 \mathrm{~h}$ at $35,000 \mathrm{rpm}$ in a Beckman 50Ti rotor). The whitish viruscontaining band was collected, diluted in $0.02 \mathrm{M}$ phosphate buffer, and submitted to a new high-speed centrifugation. The pellet was then resuspended in $2 \mathrm{ml}$ of $0.02 \mathrm{M}$ phosphate buffer. The final virus concentration was determined by spectrophotometry, using an extinction coefficient of 6 .

A viral suspension $(500 \mu \mathrm{l}$ at $2 \mathrm{mg} / \mathrm{ml})$ was emulsified with an equal volume of Freund's complete adjuvant and injected intramuscularly into the hind legs of a rabbit. Two similar injections, except that the complete adjuvant was replaced by incomplete adjuvant, were made at weekly intervals. Bleedings were started 2 weeks after the third injection.

Serological tests. Immunoglobulin Gs (IgGs) and alkaline phosphatase-conjugated IgGs were prepared according to standard procedures and used for DAS-ELISA (1). Samples were ground in the inoculation buffer at 1:10 (wt/vol) and IgGs and alkaline phosphatase-conjugated $\mathrm{IgGs}$ (each at $1 \mathrm{mg} / \mathrm{ml}$ ) were used at dilution of $1: 2,000$ and $1: 4,000$, respectively.

Electron microscopy. Crude extracts or diluted purified virus preparations were observed with a Philips CM10 (Eindhoven, The Netherlands) electron microscope using pyroxilin-coated grids and $1 \%$ ammonium molybdate, $\mathrm{pH} 7$, as a negative stain. Virus particles were measured using a carbon replica calibrated at $463 \mathrm{~nm}$ as a reference.

For cytological studies, leaf pieces $1 \mathrm{~mm}$ across were collected on the intermediate leaves from Su-95-67-infected melon plants 3 weeks after inoculation. Similar samples from healthy plants were used as controls. Samples were either directly fixed with glutaraldehyde, postfixed with osmium tetroxide, or floated on a $40 \%$ sucrose solution for $1 \mathrm{~h}$ to induce a slight cell plasmolysis before fixation. Samples were embedded in araldite CY212 (Agar Scientific Ltd., Stansted, UK). Thin sections were cut with a diamond knife using an Ultracut E (Reichert-Jung, Wien, Austria) ultramicrotome. Thin sections were stained in 5\% uranyl acetate and lead citrate, $\mathrm{pH} \mathrm{12,} \mathrm{before} \mathrm{observations} \mathrm{(2).}$

Design of Sobemovirus-specific primers. The complete nucleotide sequences of 13 sobemoviruses were retrieved from databases as follows: Rice yellow mottle virus (RYMV): U23142, L20893; Cocksfoot mottle virus (CoMV): AB040447, NC_002618; Lucerne transient streak virus (LTSV): U31286; Ryegrass mottle virus (RGMoV): AB040446; Sesbania mottle virus (SeMV): AY004291; Southern bean mosaic virus (SBMV): AF055888, AF055887, L34672; Southern cowpea mosaic virus (SCPMV): M23021; Subterreanean clover mottle virus (SCMoV): AF208001; and Turnip rosette virus (TRoV): AY177608. The sequences were aligned using the ClustalW procedure included in DAMBE (10). Two conserved domains in the region coding for the RNA-dependent RNA polymerase $(\mathrm{RdRp})$ sequences of all the viruses were selected and used to design degenerate primers Sobemo-RdRp-5': CCN TCNAARCCNGGNATGGG (amino-acid sequence: PSKPGMG) and Sobemo-RdRp-3': RTCNCCCATNGCDATRCACCA (amino acid sequence WCIAMGD, just upstream from the GDD motif present in all polymerases), with $\mathrm{N}=(\mathrm{A}, \mathrm{T}, \mathrm{G}, \mathrm{C}), \mathrm{R}=(\mathrm{A}, \mathrm{G})$, and $\mathrm{D}$ $=(A, G, T)$. The "pattern- $n$ " procedure available on the Infobiogen website (www.infobiogen.fr) was used on the sequences of the primers to check the absence of nonspecific binding with other viral or plant sequences in GenBank.

Amplification, sequencing and sequence analysis. Purified virus preparation stored at $-20^{\circ} \mathrm{C}$ in $50 \%$ glycerol was diluted $1: 5$ in distilled water and heated for $5 \mathrm{~min}$ at $65^{\circ} \mathrm{C}$; then, $1 \mu \mathrm{l}$ was used for reverse-transcription polymerase chain reaction (RT-PCR). Total RNA was extracted with TRI-reagent (Molecular Research Center Inc., Cincinnati, OH) from infected or healthy melon leaves (50 $\mathrm{mg}$ of fresh leaf for each sample) and resuspended after isopropanol precipitation in $20 \mu \mathrm{l}$ of distilled water. As controls, total RNA was also extracted from RYMV-infected and from healthy rice plants (kindly provided by D. Fargette, IRD, Montpellier, France), as well as from SBMV-infected and healthy bean plants (SBMV was kindly provided by J. P. Signoret, ENSAM, Montpellier, France).

RT was performed in a total volume of $20 \mu \mathrm{l}$, with the following conditions: $3 \mu \mathrm{l}$ of total RNA (after resuspension in $20 \mu \mathrm{l}$ of $\mathrm{H}_{2} \mathrm{O}$ ), $4 \mu \mathrm{l}$ of $5 \times$ reverse transcription buffer (Promega), $1.25 \mathrm{mM}$ each dNTP, 200 ng of primer Sobemo-RdRp-3', and 3.5 units of AMVRT (Promega) for $45 \mathrm{~min}$ at $42^{\circ} \mathrm{C}$. The cDNA ( $\left.3 \mu \mathrm{l}\right)$ was selectively amplified in a $25-\mu \mathrm{l}$ mixture containing $20 \mathrm{mM}\left(\mathrm{NH}_{4}\right)_{2} \mathrm{SO}_{4}, 75 \mathrm{mM}$ Tris-HCl (pH 9.0), 0.01\% (wt/vol) Tween 20, $2.5 \mathrm{mM} \mathrm{MgCl}_{2}, 200$ $\mu \mathrm{M}$ each dNTP, $50 \mathrm{ng}$ of primer Sobemo-RdRp-3', $120 \mathrm{ng}$ of primer Sobemo-RdRp- $5^{\prime}$, and 2 units of Taq DNA polymerase. The mixture was incubated at $94^{\circ} \mathrm{C}$ for $3 \mathrm{~min}$; followed by 35 cycles of $94^{\circ} \mathrm{C}$ for $45 \mathrm{~s}, 55^{\circ} \mathrm{C}$ for $45 \mathrm{~s}$, and $72^{\circ} \mathrm{C}$ for $1 \mathrm{~min}$; followed by a final extension at $72^{\circ} \mathrm{C}$ for $7 \mathrm{~min}$.

PCR fragments of the expected size were excised from a $1 \%$ agarose gel, purified with Qiaquick gel extraction kit (Qiagen, Courtaboeuf, France), and sent for sequencing to Genome Express (Meylan, France) using primer Sobemo-RdRp-3'. A specific oligonucleotide was designed from the sequence made available in order to obtain the sequence of the $3^{\prime}$ extremity of the fragment:Su95-67-RdRp-5': ATGGGCCTCTCTCTGGATTC. This primer was also used for specific RT-PCR amplification of SMAMV isolates from infected samples, using the same protocol as above, except that only $50 \mathrm{ng}$ of primer per reaction was introduced in the PCR mix.

The deduced amino acid sequence of Su-95-67 was aligned with the corresponding fragments of 18 Sobemovirus species or strains using the ClustalW procedure included in DAMBE (10). Distance matrixes were obtained with MEGA3 (5), using either p-distances or Kimura two-parameters and Poisson corrections for multiple substitutions for nucleotide and amino acid sequences, respec- 
tively. Neighbor-joining distance trees were obtained with MEGA3, with a bootstrap resampling (500 bootstraps).

\section{Results}

Symptomatology and host range. At 2 to 3 weeks after mechanical inoculation, isolate Su-95-67 caused severe mosaic with typical yellow patches, stunting, and leaf deformations in melon (C. melo Védrantais and snake melon) similar to those observed in the field (Fig. 1A and B). Mosaic and systemic infection was also observed in watermelon (Citrullus lanatus 'Sugar Baby').

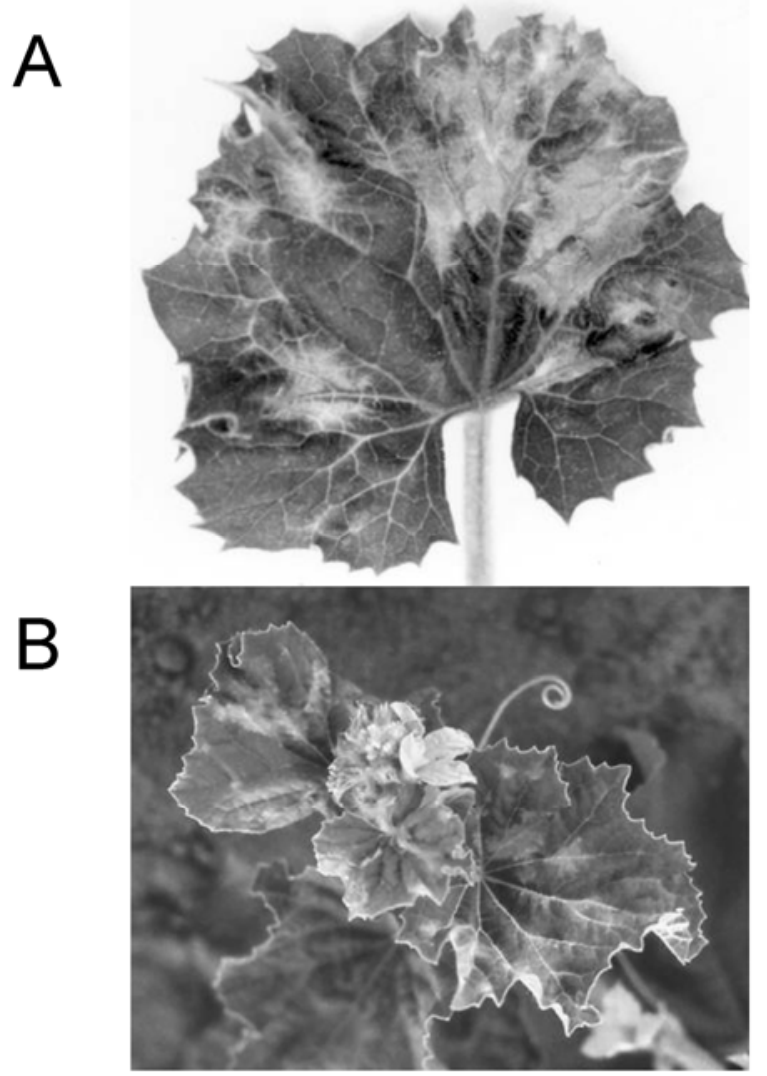

Fig. 1. Symptoms of Snake melon asteroid mosaic virus (Su95-67) A, in melon 3 weeks after mechanical inoculation and $\mathbf{B}$, in a naturally infected snake melon plant.

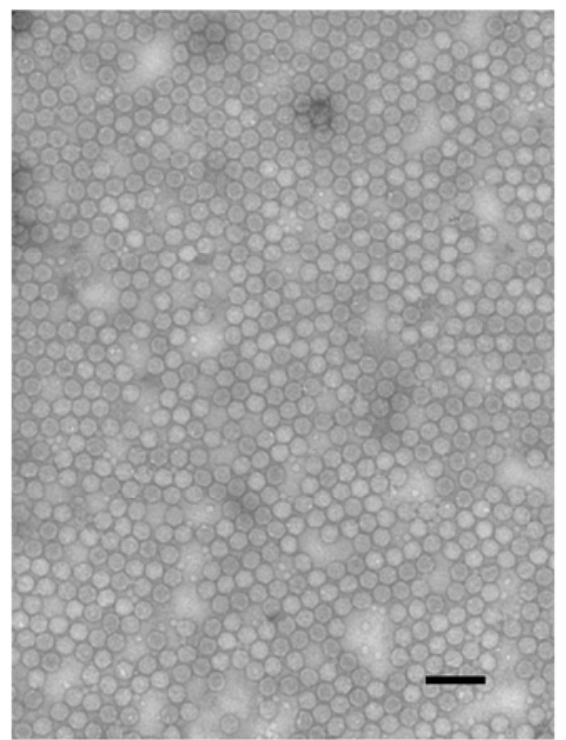

Fig. 2. Purified particles of Snake melon asteroid mosaic virus (Su95-67) negatively stained with $1 \%$ ammonium molybdate, $\mathrm{pH} 7$. Bar represent $100 \mathrm{~nm}$.
Based on the absence of symptoms and negative reactions in DAS-ELISA, no local or systemic infection was detected in cucumber (Cucumis sativus 'Marketer', 'Beit alpha', or 'TMG') and squash (Cucurbita pepo 'Diamant' and C. moschata 'Musquée de Provence'). Similarly, none of 18 non-cucurbit plant species belonging to seven families developed local or systemic infections, including Chenopodium amaranticolor, C. quinoa, Nicotiana benthamiana, N. clevelandii, N. glutinosa, Datura stramonium, tobacco, pepper, eggplant, tomato, Capsella bursa-pastoris, Ranunculus sardous, lettuce, basil, Vigna unguiculata, pea, broad bean, and bean.

Virus purification and antiserum production. The virus was purified from infected melons 3 weeks post inoculation, with a final yield of approximately $0.6 \mathrm{~g} / \mathrm{kg}$. The purified virus preparation was used to immunize a rabbit. IgGs and alkaline phosphatase-conjugated IgGs at a concentration of $1 \mathrm{mg} / \mathrm{ml}$ could be used in DAS-ELISA at a dilution up to $1 / 2,000$ and $1 / 4,000$, respectively. In standard tests, infected melon leaf samples ground 1:10 (wt/vol) in inoculation buffer gave absorbance readings at 405

A
B

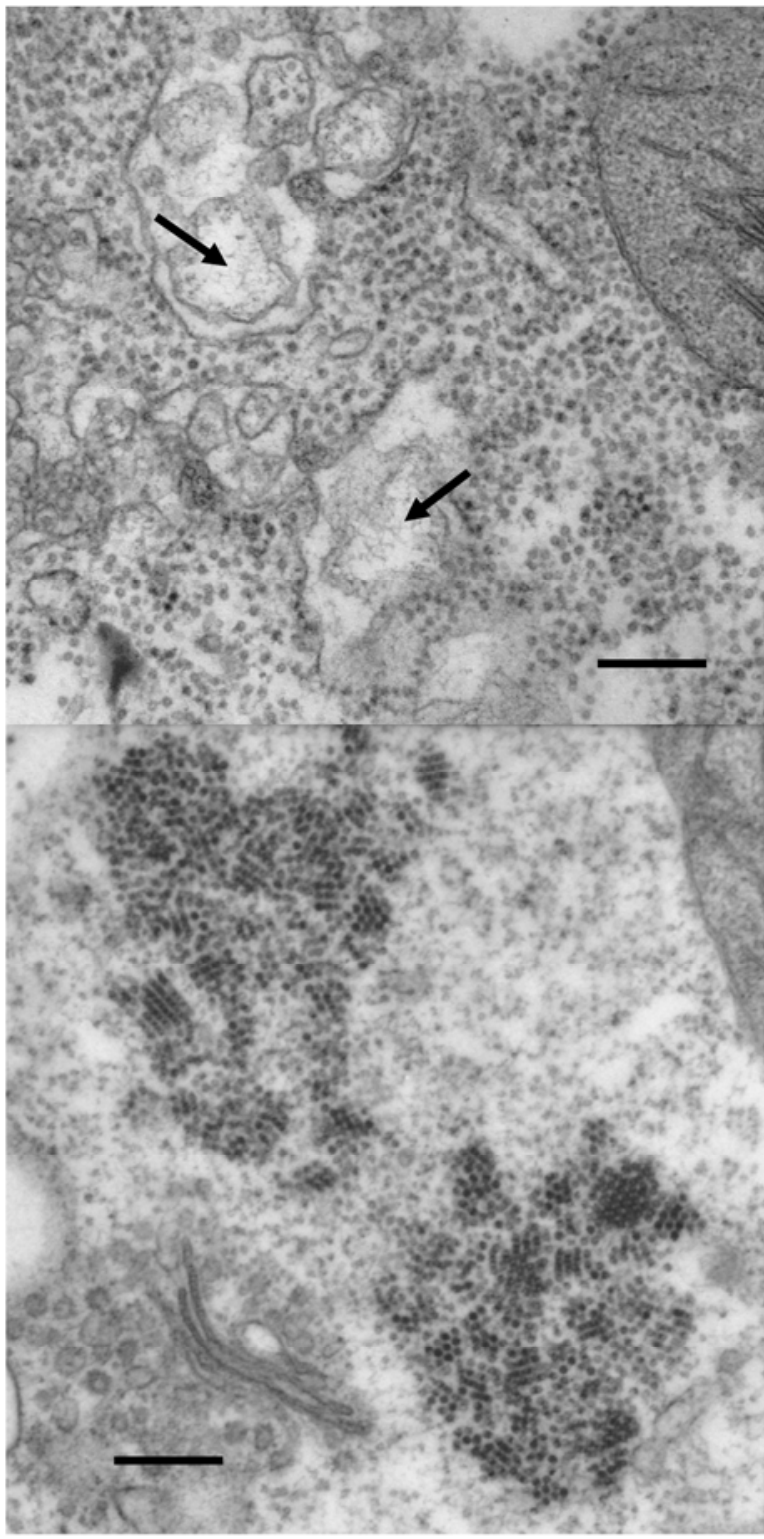

Fig. 3. Viral particles observed in parenchyma cells of a melon plant infected by Snake melon asteroid mosaic virus (Su95-67). A, Particles are difficult to differentiate from ribosomes in cell fixed and embedded directly. Arrows indicate small vesicles with fibrillar material. B, Crystalline inclusions were observed in cells submitted to a limited plasmolysis prior to fixation and embedding. Bars represent 200 $\mathrm{nm}$ 
$\mathrm{nm}$ in the range of 1.5 to 2 within $1 \mathrm{~h}$, while healthy controls had readings of 0.00 to 0.03 .

Particle morphology and cytopathology of Su-95-67. Numerous isometric particles, slightly hexagonal in shape, were observed in leaf-dip preparations from melon plants infected by Su-95-67. Purified virus preparations also contained numerous isometric particles approximately $30 \mathrm{~nm}$ in diameter, often aggregated in crystalline arrays (Fig. 2).

No cell alteration specific for a viral genus or family was observed in ultrathin sections of epidermal or parenchymatic cells from Su-95-67-infected melon plants. Numerous virus particles were observed dispersed in the cytoplasm but were hardly distinguishable from ribosomes (Fig. 3A). Cells generally appeared slightly more vacuolated than healthy controls and, occasionally, crystalline inclusions containing numerous virus particles were observed in xylem cells of older leaves (data not shown). Small vesicles containing fibrillar material were occasionally seen close to virus particles (Fig. 3A). When samples were submitted to a limited plasmolysis prior to fixation and embedding, virus particles aggregated in crystalline inclusions were clearly observed in epidermal or parenchymatic cells (Fig. 3B). Such crystalline inclusions and vesicles were not observed in healthy melon plant cells submitted to the same plasmolysis treatment (data not shown).

Seed and vector transmission. In all, 246 and 1,540 plants were obtained from Védrantais seed rinsed in water or disinfected, respectively, and 141 and 781 plants were obtained from snake melon seed rinsed in water or disinfected, respectively. Three plantlets developed symptoms soon after germination, one from snake melon seed rinsed in water and one each from Védrantaisand snake-melon-disinfected seed.

Isolate Su-95-67 was not transmitted by the melon aphid, Aphis gossypii on either the nonpersistent, semipersistent, or persistent modes.

Adults of the red melon beetle, Aulacophora foveicollis, transmitted Su-95-67 after a 3-h AAP and a 2-h IAP. In total, 34 plants were inoculated during two independent experiments. Symptoms started to appear on some plants 12 days after inoculation in the form of light mosaic and leaf deformation. After a 3-week incubation time, 8 of 18 plants in the first experiment and 9 of 16 in the second experiment developed typical symptoms. None of the control plants from the two tests developed any disease symptom. The presence of the virus was confirmed serologically.

Molecular analysis. RT-PCR yielded a 384-bp fragment, corresponding to the expected size for RYMV and SBMV as well as for purified Su-95-67 or Su-95-67-infected leaf extracts but not for healthy plant extracts. The comparison of the deduced amino acid sequence (115 amino acids) of Su-95-67 with GenPept-Virus revealed 61 to $71 \%$ identity with members of the genus Sobemovirus. The identity (Table 1) was highest with RYMV (71\%) and lowest with SBMV (61\%). Significant alignments with other viruses were restricted to members of Luteoviridae, particularly Polerovirus (42 to $45 \%$ identity in gapped alignments; data not shown). The nucleotide sequence obtained for Su-95-67 (SMAMV) was deposited into GenBank (HM450304).

A distance tree obtained for the amino acid sequences of SMAMV (Su95-67) and 18 Sobemovirus species or strains is presented in Figure 4. SMAMV clustered with RYMV and IYMV but the bootstrap support was low due to the short sequences used and high divergence between viruses. However, it is noteworthy that SMAMV clustered with RYMV and IYMV, two sobemoviruses also reported only from Africa (8).

Prevalence of SMAMV in Sudan. The prevalence of SMAMV in cucurbit crops in Sudan was estimated by testing in DAS-ELISA frozen extracts from 600 samples collected in the field from 1992 to 2003. SMAMV was detected in $61(10.2 \%)$ of the 600 samples.

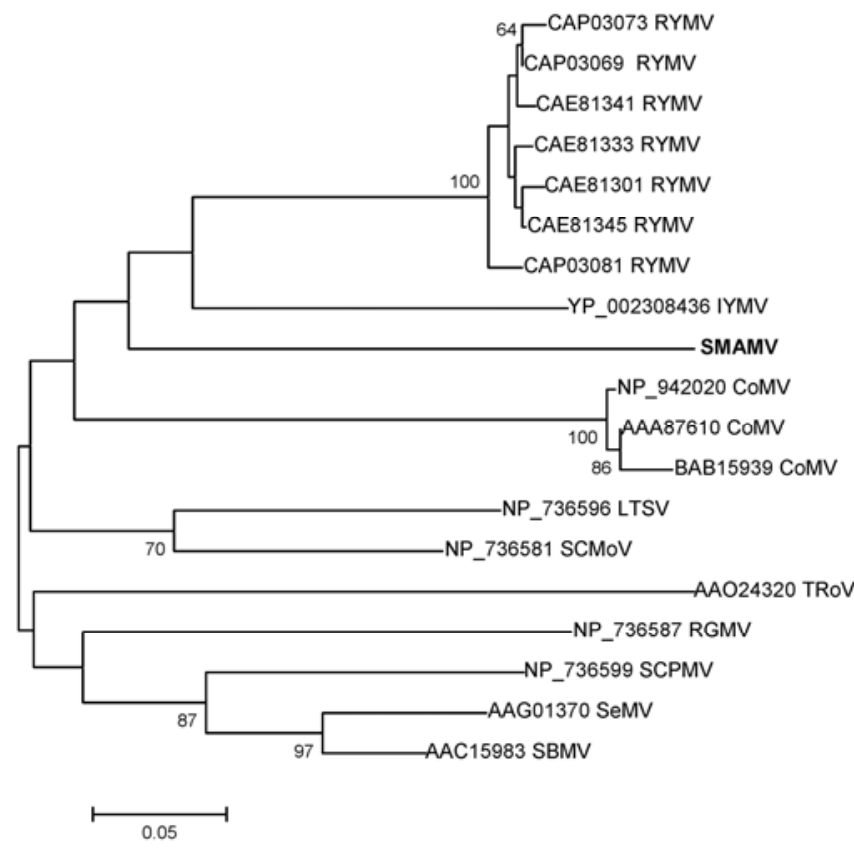

Fig. 4. Distance tree obtained from partial amino acid sequences ( 115 amino acids) of sobemovirus polymerases. GenBank protein accession numbers are indicated on the figure for each sequence. Bootstrap values above 60 are indicated for each node. The scale bar represents a genetic distance of 0.05. CoMV: Cocksfoot mottle virus; IYMV: Imperata yellow mottle virus; LTSV: Lucerne transient streak virus; RGMV: Ryegrass mosaic virus; RYMV: Rice yellow mottle virus; SBMV: Southern bean mosaic virus; SCMoV: Subterranean clover mottle virus; SCPMV: Southern cowpea mosaic virus; SeMV: Sesbania mosaic virus; TRoV: Turnip rosette virus.

Table 1. Amino acid sequence identity in a conserved fragment of the polymerase (115 amino acids) of 12 Sobemovirus species or strains and Snake melon asteroid mosaic virus (SMAMV, Su95-67)

\begin{tabular}{|c|c|c|c|c|c|c|c|c|c|c|c|c|}
\hline & \multicolumn{12}{|c|}{ Sequence identity (\%) } \\
\hline & SMAMV & RYMV & RYMV & CoMV & CoMV & SBMV & SBMV & SeMV & SCPMV & TRoV & LTSV & SCMoV \\
\hline RYMV (U23142) & 70 & $\ldots$ & $\ldots$ & $\ldots$ & $\ldots$ & $\ldots$ & $\ldots$ & $\ldots$ & $\ldots$ & $\ldots$ & $\ldots$ & $\ldots$ \\
\hline RYMV (L20893) & 71 & 99 & $\ldots$ & $\ldots$ & $\ldots$ & $\ldots$ & $\ldots$ & $\ldots$ & $\ldots$ & $\ldots$ & $\ldots$ & $\ldots$ \\
\hline CoMV (AB040447) & 66 & 69 & 69 & $\ldots$ & $\ldots$ & $\ldots$ & $\ldots$ & $\ldots$ & $\ldots$ & $\ldots$ & $\ldots$ & $\ldots$ \\
\hline CoMV (NC_002618) & 66 & 70 & 71 & 98 & $\ldots$ & $\ldots$ & $\ldots$ & $\ldots$ & $\ldots$ & $\ldots$ & $\ldots$ & $\ldots$ \\
\hline SBMV (L34672) & 61 & 67 & 68 & 65 & 66 & $\ldots$ & $\ldots$ & $\ldots$ & $\ldots$ & $\ldots$ & $\ldots$ & $\ldots$ \\
\hline SBMV (AF055888) & 66 & 72 & 73 & 70 & 72 & 94 & $\ldots$ & $\ldots$ & $\ldots$ & $\ldots$ & $\ldots$ & $\ldots$ \\
\hline SeMV (AY004291) & 66 & 72 & 72 & 68 & 69 & 87 & 91 & $\ldots$ & $\ldots$ & $\ldots$ & $\ldots$ & $\ldots$ \\
\hline SCPMV (NC_001625) & 66 & 70 & 71 & 72 & 74 & 78 & 83 & 83 & $\ldots$ & $\ldots$ & $\ldots$ & $\ldots$ \\
\hline TRoV (NC_004553) & 66 & 66 & 67 & 61 & 61 & 65 & 70 & 69 & 68 & $\ldots$ & $\ldots$ & $\ldots$ \\
\hline LTSV (U31286) & 63 & 68 & 69 & 71 & 72 & 67 & 72 & 70 & 72 & 67 & $\ldots$ & $\ldots$ \\
\hline SCMoV (NC_004346) & 66 & 72 & 72 & 65 & 67 & 68 & 73 & 71 & 68 & 63 & 80 & $\ldots$ \\
\hline RGMV (AB040446) & 63 & 67 & 68 & 67 & 68 & 68 & 72 & 72 & 72 & 65 & 71 & 73 \\
\hline
\end{tabular}

${ }^{a}$ CoMV: Cocksfoot mottle virus; LTSV: Lucerne transient streak virus; RGMV: Ryegrass mosaic virus; RYMV: Rice yellow mottle virus; SBMV: Southern bean mosaic virus; SCMoV: Subterranean clover mottle virus; SCPMV: Southern cowpea mosaic virus; SeMV: Sesbania mosaic virus; TRoV: Turnip rosette virus. 
It was detected in snake melon (17\% of 272 samples), melon ( $8 \%$ of 89 samples), tibish (a cultivated form of Cucumis melo var. agrestis, $4 \%$ of 26 samples), a wild Cucumis sp. (5\% of 44 samples), and watermelon (6\% of 91 samples). SMAMV was not detected in the 78 squash samples tested. The geographical distribution of SMAMV seems to be very wide in Sudan. SMAMV was found along the Nile River, from Er Roseires (Blue Nile State) in the south to Atbara (Nile State) in the north, and from the Gash delta (Kassala State) in the east to El Obeid (Northern Kordofan State) in the west. The prevalence of SMAMV was extremely variable from place to place. In snake melon fields where significant numbers of samples (more than 10) were collected, infection rates varied from 8 to $69 \%$.

\section{Discussion}

Isolate Su-95-67 has properties different from those of any cucurbit virus reported so far. Particle morphology, the lack of a characteristic cytological "signature" in infected cells but the presence of numerous virus particles and small vesicles with fibrillar material in the cytoplasm, seed transmission, transmission by beetles, and a restricted host range suggested that Su-95-67 could be related to sobemoviruses (3). This relationship was further established by using the generic Sobemovirus primers that have been developed. These primers amplified successfully a fragment of 384 bp of the polymerase domain of two sobemoviruses (RYMV and SBMV) and a similar fragment was obtained for Su-95-67. A phylogenetic analysis confirmed that Su-95-67 grouped with members of the genus Sobemovirus (Fig. 4); however, longer sequences will be required to determine more precisely the taxonomic position of SMAMV. Indeed, the International Committee for Taxonomy of Viruses provides, as a criterion for species demarcation within genus Sobemovirus, a minimum value of $40 \%$ sequence differences for the whole virus genome (4). We have only a small sequence fragment of Su-95-67 genome within the polymerase domain, a highly conserved region in viral genomes (9). However, nine different sobemoviruses have amino acid sequence differences in that specific fragment ranging from 9 to $39 \%$ whereas, for different strains from the same species, the differences ranged from 4 to $6 \%$ (Table 1). A similar grouping was observed when using more than 50 Sobemovirus sequences (data not shown). With nine different sobemoviruses, Su-95-67 has sequence differences ranging from 29 to $39 \%$ (Table 1), corresponding to the range observed between distinct species of the genus Sobemovirus.

Based on these biological and molecular properties, we propose that Su-95-67 represents a tentative new member of the genus Sobemovirus, SMAMV, from snake melon, the host from which it was first isolated, and based on the typical symptoms it induces in this host (star-shaped chlorotic spots and mosaic). SMAMV is the first member of the genus Sobemovirus reported to naturally infect cucurbit crops.

SMAMV was observed to be widespread in Sudan, particularly along the Nile River, where it constitutes a potential threat for melon and watermelon crops. It is particularly frequent in snake melon, alone or in mixed infection with other cucurbit viruses (ZYMV, MWMV, CABYV, or WmCSV). Farmers usually produce their own snake melon seed and the observed seed transmission, even at a low rate, could constitute an efficient means of virus transmission from one crop to another. In addition, SMAMV also infects wild Cucumis spp. which could constitute intercrop reservoirs.

Seed transmission is also important for germplasm exchanges, and special care should be taken for keeping melon and watermelon genetic resources free from this virus. It would be interesting to determine the extent of SMAMV geographical distribution in Eastern Africa, and particularly whether this virus also occurs in neighboring countries (Ethiopia, Eritrea, or Egypt).

\section{Acknowledgments}

We thank D. Fargette (IRD, Montpellier) and J. P. Signoret (ENSAM, Montpellier) for providing RYMV and SBMV samples, respectively.

\section{Literature Cited}

1. Clark, M. F., and Adams, A. N. 1977. Characteristics of the microplate method of enzyme-linked immunosorbent assay for the detection of plant viruses. J. Gen. Virol. 34:475-483.

2. Delécolle, B. 1978. Essais de rationalisation des méthodes de préparation d'échantillons végétaux pour la microscopie électronique: problème des précipités parasites. Cell. Mol. Biol. 23:431-436.

3. Hull, R. 1988. The Sobemovirus group. Pages 113-145 in: The Plant Viruses, vol. 3, Polyhedral Virions with Monopartite RNA Genomes. R. Koenig, ed. Plenum Press, New York.

4. Hull, R., and Fargette, D 2005. Sobemovirus. Pages 885-890 in: Virus Taxonomy: Eighth Report of the International Committee on Taxonomy of Viruses. C. M. Fauquet, M. A. Mayo, J. Maniloff, U. Desselberger, and L. A. Ball, eds. Elsevier, London.

5. Kumar, S., Tamura, K., and Nei M. 2004. MEGA3: Integrated software for molecular evolutionary genetic analysis and sequence alignment. Brief. Inf. 5:150-163.

6. Lecoq, H., Dafalla, G. A., Desbiez, C., Wipf-Scheibel, C., and Kheyr-Pour, A. 2003. A 10-year survey (1993-2002) of cucurbit viruses in Sudan. J. Plant Dis. Prot. 110:68-69.

7. Lecoq, H., Dafalla, G. A., Mohamed, Y. F., Ali, H. M., Wipf-Scheibel, C. Desbiez, C., Eljack, A. E., Omara, S. K., and Pitrat, M. 1995. Survey of virus diseases infecting cucurbit crops in eastern, central and western Sudan. J. Sud. Agric. 2:67-82.

8. Sérémé, D., Lacombe, S., Konaté, M., Pinel-Galzi, A., Traoré, V. S. E., Hébrard, E., Traoré, O., Brugidou, C., Fargette, D., and Konaté, G. 2008. Biological and molecular characterization of a putative new sobemovirus infecting Imperata cylindrica and maize in Africa. Arch. Virol. 153:18131820.

9. Tamm, T., and Truve, E. 2000. Sobemoviruses. J. Virol. 74:6231-6241.

10. Xia, X. 2000. Data Analysis in Molecular Biology and Evolution. Kluwer Academic Publishers, Boston/Dordrecht/London. 